\title{
An assessment of orchids' diversity in Penang Hill, Penang, Malaysia after 115 years
}

\author{
Rusea Go $\cdot$ Khor Hong Eng • Muskhazli Mustafa • Janna Ong Abdullah • \\ Ahmad Ainuddin Naruddin • Nam Sook Lee • Chang Shook Lee • \\ Sang Mi Eum • Kwang-Woo Park $\cdot$ Kyung Choi
}

Received: 22 September 2010/ Accepted: 3 June 2011/Published online: 12 June 2011

(C) The Author(s) 2011. This article is published with open access at Springerlink.com

\begin{abstract}
A comprehensive study on the orchid diversity in Penang Hill, Penang, Malaysia was conducted from 2004 to 2008 with the objective to evaluate the presence of orchid species listed by Curtis (J Strait Br R Asiat Soc 25:67-173, 1894) after more than 100 years. A total of 85 species were identified during this study, of which 52 are epiphytic or lithophytic and 33 are terrestrial orchids. This study identified 57 species or $64.8 \%$ were the same as those recorded by Curtis (1894), and 78 species or $66.1 \%$ of Turner's (Gardens' Bull Singap 47(2):599-620, 1995) checklist of 118 species for the state of Penang including 18 species which were not recorded by Curtis (1894) and the current study but are actually collected from Penang Hill. A comparison table of the current findings against Curtis (1894) and Turner (1995) is provided which shows only 56 species were the same in all three studies. The preferred account for comparison was Curtis' (1894) list as his report was specifically for the areas around Penang Island especially Penang Hill, Georgetown and Ayer Itam areas. Our study reveals that about 50\% of Curtis' collection localities have been converted to residential areas and agricultural land, and this probably explains the decreasing numbers of species found in the current study especially for the terrestrial species as epiphytic species have better adaptation capabilities towards environmental
\end{abstract}

R. Go $(\bowtie) \cdot$ K. H. Eng · M. Mustafa

Department of Biology, Faculty of Science, Universiti Putra Malaysia,

43400 UPM Serdang, Selangor, Malaysia

e-mail: rusea@science.upm.edu.my

J. O. Abdullah

Department of Microbiology, Faculty of Biotechnology and Cell Biomolecule, Universiti Putra

Malaysia, 43400 UPM Serdang, Selangor, Malaysia

R. Go - A. A. Naruddin

Institute of Tropical Forestry and Forest Products, Universiti Putra Malaysia,

43400 UPM Serdang, Selangor, Malaysia

N. S. Lee $\cdot$ C. S. Lee $\cdot$ S. M. Eum

Department of Life Science, Ewha Womans University, Seoul 120-750, Korea

K.-W. Park · K. Choi

National Arboretum, Gyeonggi-do 487-821, Korea 
changes. Seven species were identified as new records to Penang Hill as they were not recorded by Curtis (1894). None of the three species recorded as endemic to Penang by Turner (1995) was recollected during the current study, of which only Zeuxine rupestris was in Curtis' (1894) list. Overall, we concluded that Penang hill harbours at least 136 species of orchids of which 78 species or $57.4 \%$ were recollected in this study. This also indicates that this area is still suitable for orchid growth even though it is surrounded by rapid development and mass conversion of forested land into fruit orchards and residential area. The designation of Penang Hill as a Permanent Forest Reserve would better guarantee the survival of some orchid species unless human interventions and climatic changes occur.

Keywords Orchid · Diversity · Threat · Penang Hill · Malaysia

\section{Introduction}

Penang Hill or Bukit Bendera as it is known in Malay, is located in Penang Island. It consists of a few peaks, the Western Hill which is the highest peak of $833 \mathrm{~m}(2,723 \mathrm{ft})$ above sea level, Bukit Laksamana, Tiger Hill, Government Hill, and Flagstaff Hill, the second highest peak of $735 \mathrm{~m}(2,450 \mathrm{ft})$. This hill system is mainly made up of hilly granitic mass with most of the hills being more than $700 \mathrm{~m}$ high. It has a cooler climate with temperatures ranging from 20 to $27^{\circ} \mathrm{C}$ and a mean minimum temperature below $21^{\circ} \mathrm{C}$. It is an ideal retreat place both for the locals as well as for foreign tourists.

Botanical studies have started ever since the British arrived in Penang, as early as in the 1790s. Many local plants were identified, and new plants from elsewhere were introduced and planted in Penang for commercial purposes. Many plant specimens were collected by foreign botanists and sent back to their respective countries as herbarium specimens and living collections (Burkill 1966).

In 1894, Curtis published an account on his own orchid collection in Penang which consisted of 90 species from 46 genera, in this historical publication 'A Catalogue of the Flowering Plants \& Ferns Found Growing Wild in the Island of Penang'. Turner (1995), however, revised the specimens deposited in the Singapore Botanical Garden's Herbarium (SING), the Royal Botanic Gardens at Kew, England (KEW), and local herbaria in the Forest Research Institute of Malaysia in Kepong (KEP), University Malaya (KLU), Biology Department, Universiti Putra Malaysia (UPM) and Universiti Kebangsaan Malaysia (UKMB) and published a comprehensive vascular plant checklist for Malaya (Peninsular Malaysia). In the checklist, he listed 140 species of orchids with specific reference to Penang which included three endemic species, Cheirostylis goldschmidtiana, Eria diluta, and Zuexine rupestris. Cheah (2005), however, listed 26 species of terrestrial and lithophytic orchids, and Loy (2005) listed 35 species of epiphytic orchids. The above findings including new data collected after 2005 are presented and discussed in this paper.

The Penang flora is indeed very important as they are the remnants of the large forest of Peninsular Malaysia that is still surviving on this small island. Many of the island's previously common plants are now uncommon and rare due to human activities. For instance, the slipper orchid, Paphiopedillum callosum var. sublaeve which was wrongly identified as Paphiopedilum barbatum by Khor et al. (1991) and a species which used to be common in Penang, is currently becoming rare due to over-collection and habitat destruction. P. barbatum was never collected in Penang even though it was a widespread species. This confusion maybe due to the fact that Curtis (1894) listed Cyripedium 
barbatum as one of the species, but this is a synonym of $P$. callosum var. sublaeve and not a basionym for $P$. barbatum.

\section{Materials and methods}

Five field observations and botanical collection trips were carried out from 2004 to 2008 along 18 forest trails: Cendana Hill Trail, Trail 5, Lily Pond, Mount Olivia Trail, Waterfall Trail, Summit Road, Government Hill Trail, Viaduct Road, South View Road, Moniot Road West, Moniot Road East, Path E, Upper Tunnel Road West, Upper Tunnel Road East, Lower Tunnel Road, Jeep Track, Middle Station and Western Hill Trail. The specimens were collected as living collections for those non-flowering materials and as herbarium specimens for both the non-flowering and flowering materials. The living specimens were transplanted in the greenhouse in Universiti Putra Malaysia for ex situ conservation and identification once they flowered. Flowered materials were then preserved as herbarium specimens and the flowers as spirit collections. All macro morphological characters, such as vegetative and floral structures, were observed and recorded in the field and also at the green house. The herbarium specimens were processed according to the standard herbarium specimen preparation techniques as outlined by Bridson and Forman (1989). Specimens were identified using the characters described and the identification keys in Holtum (1957), Seidenfaden and Wood (1992), and Comber (1990, 2001). Scientific names adopted here are those accepted by the latest Kew World Checklist of Selected Plant Families accessed via the web. All the herbarium specimens collected and studied were kept in the Herbarium of the Biology Department at the Faculty of Science, Universiti Putra Malaysia (UPM). Specimens in herbaria locally and abroad were also studied, especially those at the Singapore Botanical Garden (SING), the Royal Botanic Gardens Kew Herbarium (K), University Malaya (KLU), FRIM (KEP), and Universiti Kebangsaan Malaysia (UKMB) for further verification.

\section{Results and discussion}

A total of eighty five orchid species from 61 genera were collected during the period of study, of which 52 are epiphytic or lithophytic and thirty three are terrestrial. Seven species were identified as new records for the Penang Hill. The seven species are Bulbophyllum biflorum, Coelogyne septemcostata, Cymbidium haematodes, Dendrobium convexa, Lepidogyne longifolia, Liparis barbata and Thrixspermum duplocallosum. B. biflorum was previously recorded only from Pahang and Selangor by Turner (1995) but currently is known to be widespread within Malaysia. C. septemcostata and L. longifolia was previously only recorded as lowland forest species in Pahang and Johore. C. haematodes, however, was only known from Pulau Langkawi. D. convexa was previously found in Pontian, Johore and Ulu Kali, Selangor. L. barbata was previously documented in Perak, Tioman Island and Johore. Besides the new records, there were also some species collected which are common to Penang but not to Peninsular Malaysia, except for certain localities, such as Acriopsis indica, Campanulorchis leiophylla and Hetaeria oblongifolia.

Eria, Dendrobium and Bulbophyllum were among the genera with the most species found in this study site. The Western Hill exhibited a high diversity of orchid as the highest number of orchids was recorded from the Western Hill Trail. This correlates with the elevation of the land as the Western Hill is the highest peak in the Penang Hill system. The higher elevation provides a suitable environment for the orchids to thrive as the 
temperature is lower and the humidity is higher. The Moniot Road East, Moniot Road West, Government Hill Trail and Cendana Hill Trail were also among the selected trails where more than six species were collected. The other trails visited, however, exhibited a lower diversity. This might be due to the rapid development of the town and some recreational areas which affected orchid growth.

Most of the orchid specimens collected are epiphytic and lithophytic. There were also several terrestrials. This is because of the limited soils or humus to support plant growth as there are numerous huge granite borders and outcrops in this area. Hence, most of the orchids are growing abundantly on tree trunks and rocks layered with plant sediments or humus. Some variations of characters, such as colour of flowers, leave sizes and overall plant size differ among the collected specimens and the cited specimens in the references. This phenomenon might possibly be due to environmental and genetic factors which should be further explored. Besides that, most of the specimens collected were from the higher altitudes, at $700 \mathrm{~m}$ upwards. In addition, the abundance of species was low as most of the species were observed as individual plants or small populations of 2-3 plants.

The current orchid diversity in Penang is listed in Table 1, which is a compilation of species recorded by Curtis (1894) and Turner (1995) and results from the current study. A total of 136 species were found in Penang Hill. This study recorded an additional seven species as new records to Penang. The diversity when compared to those reported by Curtis (1894) revealed that only 21 species listed by him were not collected during the current study. This could be explained as more than $70 \%$ of the species collected are epiphytic orchids and they have better adaptations to environmental changes when compared to the terrestrials. Apart from that, Curtis' (1894) collections that were not collected during the current study were actually obtained from areas that are now residential and fruit tree orchards. The conversion of forested areas for development is an irreversible destruction which could wipe out species from any kinds of habitat.

Turner (1995) listed a total of 118 species of orchids recorded for the state of Penang which includes the 18 species not recorded by Curtis (1894) or this current study but were collected from Penang Hill as recorded by Seidenfaden and Wood (1992). He also listed three species as endemic to Penang, namely Cheirostylis goldschidtiana, E. diluta and Zeuxine rupestris. C. goldschmidtiana and E. diluta were both not recorded by Curtis (1894) and this study but they were recorded by Seidenfaden and Wood (1992), which included the locality of the specimens studied. For $E$. diluta, there are two specimens belonging to this species in the Kew Herbarium $(\mathrm{K})$ of which the type was actually collected from Kedah Peak (Gunung Jerai), Kedah. Therefore, it should not be listed as endemic to Penang as claimed by Turner (1995). The second collection was from Pantai Aceh, Penang, which is not part of the Penang Hill complex. C. goldschmidtiana was recorded in Penang based on a single record collected in 1912 at Bukit Bendera (Penang Hill) and was never collected again from here (Seidenfaden and Wood 1992). However, the same species was recently (January, 2010) collected in Baling, Kedah by Rogier van Vugt and the photographs were published online in the Website of the Swiss Orchid Foundation of the Herbarium Jany Renz which is operating under the patronage of the University of Basel, Switzerland (accessed on 12 May, 2011). With this discovery, C. goldschmidtiana is no longer endemic to Penang but still an endemic to Peninsular Malaysia. Nevertheless, it is worthwhile to further search for this species around Penang Hill, otherwise considered extinct from this location. Z. rupestris, however, was recorded by Curtis, which was based on a single record from Bukit Bendera (Penang Hill) at $700 \mathrm{~m}$ altitude (Seidenfaden and Wood 1992) but was not found in the present study. Unfavourable environmental condition (currently higher temperature and frequent prolonged 
Table 1 Comparison of orchid species found in Penang Hill during the current study with those listed by Curtis (1894)

\begin{tabular}{|c|c|c|c|c|}
\hline No. & Species & Curtis (1894) & Turner (1995) & Current study \\
\hline 1. & Acampe rigida & $\sqrt{ }$ & $\sqrt{ }$ & \\
\hline 2. & Acanthephippium javanicum & & $\sqrt{ }$ & \\
\hline 3. & Acriopsis indica & $\sqrt{ }$ & $\sqrt{ }$ & $\sqrt{ }$ \\
\hline 4. & Acriopsis liliifolia & $\sqrt{ }$ & $\sqrt{ }$ & $\sqrt{ }$ \\
\hline 5. & Aerides odorata & $\sqrt{ }$ & $\sqrt{ }$ & $\sqrt{ }$ \\
\hline 6. & Agrostophyllum majus & $\sqrt{ }$ & $\sqrt{ }$ & $\sqrt{ }$ \\
\hline 7. & Agrostophyllum stipulatum & $\sqrt{ }$ & $\sqrt{ }$ & $\sqrt{ }$ \\
\hline 8. & Ainia penangiana & $\sqrt{ }$ & $\sqrt{ }$ & $\sqrt{ }$ \\
\hline 9. & Anoectochilus albolineatus & $\sqrt{ }$ & $\sqrt{ }$ & $\sqrt{ }$ \\
\hline 10. & Anoectochilus brevistylus & $\sqrt{ }$ & $\sqrt{ }$ & \\
\hline 11. & Apostasia wallichii & $\sqrt{ }$ & $\sqrt{ }$ & $\sqrt{ }$ \\
\hline 12. & Appendicula anceps & $\sqrt{ }$ & $\sqrt{ }$ & $\sqrt{ }$ \\
\hline 13. & Appendicula pendula & $\sqrt{ }$ & $\sqrt{ }$ & \\
\hline 14. & Arundina graminifolia & & $\sqrt{ }$ & $\sqrt{ }$ \\
\hline 15. & Bromheadia finlaysoniana & $\sqrt{ }$ & $\sqrt{ }$ & $\sqrt{ }$ \\
\hline 16. & Bromheadia truncata & & $\sqrt{ }$ & $\sqrt{ }$ \\
\hline 17. & Bulbophyllum angustifolium & $\sqrt{ }$ & $\sqrt{ }$ & \\
\hline 18. & Bulbophyllum biflorum** & & & $\sqrt{ }$ \\
\hline 19. & Bulbophyllum bisetum & $\sqrt{ }$ & $\sqrt{ }$ & \\
\hline 20. & Bulbophyllum blepharistes & $\sqrt{ }$ & $\sqrt{ }$ & \\
\hline 21. & Bulbophyllum corolliferum & & $\sqrt{ }$ & \\
\hline 22. & Bulbophyllum haniffii & & $\sqrt{ }$ & $\sqrt{ }$ \\
\hline 23. & Bulbophyllum hirtulum & & $\sqrt{ }$ & \\
\hline 24. & Bulbophyllum inunctum & & $\sqrt{ }$ & \\
\hline 25. & Bulbophyllum lasianthum & & $\sqrt{ }$ & $\sqrt{ }$ \\
\hline 26. & Bulbophyllum leptosepalum & $\sqrt{ }$ & $\sqrt{ }$ & $\sqrt{ }$ \\
\hline 27. & Bulbophyllum medusae & $\sqrt{ }$ & $\sqrt{ }$ & $\sqrt{ }$ \\
\hline 28. & Bulbophyllum membranceum & & $\sqrt{ }$ & $\sqrt{ }$ \\
\hline 29. & Bulbophyllum obtusum & & $\sqrt{ }$ & $\sqrt{ }$ \\
\hline 30. & Bulbophyllum pileatum & $\sqrt{ }$ & $\sqrt{ }$ & $\sqrt{ }$ \\
\hline 31. & Bulbophyllum pulchellum & $\sqrt{ }$ & $\sqrt{ }$ & \\
\hline 32. & Bulbophyllum uniflorum & & $\sqrt{ }$ & $\sqrt{ }$ \\
\hline 33. & Bulbophyllum vaginatum & $\sqrt{ }$ & $\sqrt{ }$ & $\sqrt{ }$ \\
\hline 34. & Calanthe pulchra & $\sqrt{ }$ & $\sqrt{ }$ & $\sqrt{ }$ \\
\hline 35. & Callostylis pulchella & $\sqrt{ }$ & $\sqrt{ }$ & $\sqrt{ }$ \\
\hline 36. & Campanulorchis leiophylla & $\sqrt{ }$ & $\sqrt{ }$ & $\sqrt{ }$ \\
\hline 37. & Campanulorchis pellipes & $\sqrt{ }$ & $\sqrt{ }$ & $\sqrt{ }$ \\
\hline 38. & Ceratostylis pendula & & $\sqrt{ }$ & $\sqrt{ }$ \\
\hline 39. & Cheirostylis goldschmidtiana* & & $\sqrt{ }$ & \\
\hline 40. & Cheirostylis montana & & $\sqrt{ }$ & \\
\hline 41. & Cheirostylis pusilla & & $\sqrt{ }$ & \\
\hline 42. & Claderia viridiflora & $\sqrt{ }$ & $\sqrt{ }$ & $\sqrt{ }$ \\
\hline 43. & Cleistoma scortechinii & $\sqrt{ }$ & $\sqrt{ }$ & \\
\hline
\end{tabular}


Table 1 continued

\begin{tabular}{|c|c|c|c|c|}
\hline No. & Species & Curtis (1894) & Turner (1995) & Current study \\
\hline 44. & Cleistoma subulatum & $\sqrt{ }$ & $\sqrt{ }$ & \\
\hline 45. & Coelogyne cumingii & $\sqrt{ }$ & $\sqrt{ }$ & \\
\hline 46. & Coelogyne mayeriana & & $\sqrt{ }$ & $\sqrt{ }$ \\
\hline 47. & Coelogyne rochussenii & $\sqrt{ }$ & $\sqrt{ }$ & $\sqrt{ }$ \\
\hline 48. & Coelogyne septemcostata** & & & $\sqrt{ }$ \\
\hline 49. & Coelogyne trinervis & & $\sqrt{ }$ & $\sqrt{ }$ \\
\hline 50. & Coelogyne velutina & $\sqrt{ }$ & & $\sqrt{ }$ \\
\hline 51. & Corymborkis veratrifolia & $\sqrt{ }$ & $\sqrt{ }$ & $\sqrt{ }$ \\
\hline 52. & Crepidium calophyllum & & $\sqrt{ }$ & \\
\hline 53. & Cryptostylis arachnites & $\sqrt{ }$ & $\sqrt{ }$ & $\sqrt{ }$ \\
\hline 54. & Cymbidium finlaysonianum & $\sqrt{ }$ & $\sqrt{ }$ & $\sqrt{ }$ \\
\hline 55. & Cymbidium haematodes** & & & $\sqrt{ }$ \\
\hline 56. & Dendrobium aloifolium & $\sqrt{ }$ & $\sqrt{ }$ & $\sqrt{ }$ \\
\hline 57. & Dendrobium anosmum & & $\sqrt{ }$ & $\sqrt{ }$ \\
\hline 58. & Dendrobium bancana & & $\sqrt{ }$ & $\sqrt{ }$ \\
\hline 59. & Dendrobium bifarium & $\sqrt{ }$ & $\sqrt{ }$ & $\sqrt{ }$ \\
\hline 60. & Dendrobium concinnum & & $\sqrt{ }$ & $\sqrt{ }$ \\
\hline 61. & Dendrobium convexum** & & & $\sqrt{ }$ \\
\hline 62. & Dendrobium crumenatum & $\sqrt{ }$ & $\sqrt{ }$ & $\sqrt{ }$ \\
\hline 63. & Dendrobium excavatum & & $\sqrt{ }$ & \\
\hline 64. & Dendrobium farmeri & & $\sqrt{ }$ & \\
\hline 65. & Dendrobium grande & $\sqrt{ }$ & $\sqrt{ }$ & $\sqrt{ }$ \\
\hline 66. & Dendrobium leonis & $\sqrt{ }$ & $\sqrt{ }$ & $\sqrt{ }$ \\
\hline 67. & Dendrobium metrium & & $\sqrt{ }$ & \\
\hline 68. & Dendrobium pachyphyllum & $\sqrt{ }$ & $\sqrt{ }$ & \\
\hline 69. & Dendrobium plicatile & & $\sqrt{ }$ & $\sqrt{ }$ \\
\hline 70. & Dendrobium sanguinolentum & $\sqrt{ }$ & $\sqrt{ }$ & $\sqrt{ }$ \\
\hline 71. & Dendrobium secundum & $\sqrt{ }$ & $\sqrt{ }$ & $\sqrt{ }$ \\
\hline 72. & Dendrobium singaporense & & $\sqrt{ }$ & \\
\hline 73. & Dendrobium sinuatum & $\sqrt{ }$ & $\sqrt{ }$ & $\sqrt{ }$ \\
\hline 74. & Dendrobium subulatum & $\sqrt{ }$ & $\sqrt{ }$ & \\
\hline 75. & Dendrobium villosulum & $\sqrt{ }$ & $\sqrt{ }$ & \\
\hline 76. & Dendrobium xantholeucum & $\sqrt{ }$ & $\sqrt{ }$ & \\
\hline 77. & Dienia ophrydis & $\sqrt{ }$ & $\sqrt{ }$ & $\sqrt{ }$ \\
\hline 78. & Dipodium pictum & & $\sqrt{ }$ & $\sqrt{ }$ \\
\hline 79. & Dipodium scandens & & $\sqrt{ }$ & $\sqrt{ }$ \\
\hline 80. & Eria neglecta & $\sqrt{ }$ & $\sqrt{ }$ & $\sqrt{ }$ \\
\hline 81. & Eria nutans & $\sqrt{ }$ & $\sqrt{ }$ & $\sqrt{ }$ \\
\hline 82. & Eria ornata & & $\sqrt{ }$ & $\sqrt{ }$ \\
\hline 83. & Erythrorchis altissima & $\sqrt{ }$ & $\sqrt{ }$ & \\
\hline 84. & Eulophia andamanensis & & $\sqrt{ }$ & $\sqrt{ }$ \\
\hline 85. & Eulophia spectabilis & $\sqrt{ }$ & $\sqrt{ }$ & $\sqrt{ }$ \\
\hline 86. & Galeola nudifolia & $\sqrt{ }$ & $\sqrt{ }$ & \\
\hline
\end{tabular}


Table 1 continued

\begin{tabular}{|c|c|c|c|c|}
\hline No. & Species & Curtis (1894) & Turner (1995) & Current study \\
\hline 87. & Geodorum citrinum & $\sqrt{ }$ & $\sqrt{ }$ & $\sqrt{ }$ \\
\hline 88. & Geodorum densiflorum & $\sqrt{ }$ & $\sqrt{ }$ & \\
\hline 89. & Goodyera viridiflora & & $\sqrt{ }$ & $\sqrt{ }$ \\
\hline 90. & Grammatophyllum speciosum & $\sqrt{ }$ & $\sqrt{ }$ & $\sqrt{ }$ \\
\hline 91. & Habenaria rhodocheila & & $\sqrt{ }$ & $\sqrt{ }$ \\
\hline 92. & Hetaeria nitida & & $\sqrt{ }$ & \\
\hline 93. & Hetaeria obliqua & $\sqrt{ }$ & $\sqrt{ }$ & \\
\hline 94. & Hetaeria oblongifolia & & $\sqrt{ }$ & $\sqrt{ }$ \\
\hline 95. & Lepidogyne longifolia** & & & $\sqrt{ }$ \\
\hline 96. & Liparis barbata** & & & $\sqrt{ }$ \\
\hline 97. & Liparis maingayi & $\sqrt{ }$ & $\sqrt{ }$ & $\sqrt{ }$ \\
\hline 98. & Ludisia discolor & $\sqrt{ }$ & $\sqrt{ }$ & \\
\hline 99. & Luisia curtisii & $\sqrt{ }$ & $\sqrt{ }$ & \\
\hline 100. & Macodes petola & & $\sqrt{ }$ & \\
\hline 101. & Nervilia plicata & & $\sqrt{ }$ & \\
\hline 102. & Nervilia punctata & $\sqrt{ }$ & $\sqrt{ }$ & \\
\hline 103. & Neuwiedia veratrifolia & $\sqrt{ }$ & $\sqrt{ }$ & $\sqrt{ }$ \\
\hline 104. & Neuwiedia zollingeri var. singapureana & $\sqrt{ }$ & $\sqrt{ }$ & \\
\hline 105. & Oberonia lycopodioides & $\sqrt{ }$ & $\sqrt{ }$ & $\sqrt{ }$ \\
\hline 106. & Oberonia pumilio & & $\sqrt{ }$ & \\
\hline 107. & Odontochilus uniflorus & $\sqrt{ }$ & $\sqrt{ }$ & \\
\hline 108. & Paphiopedilum callosum var. sublaeve & $\sqrt{ }$ & $\sqrt{ }$ & \\
\hline 109. & Peristylus lacertifer & $\sqrt{ }$ & $\sqrt{ }$ & \\
\hline 110. & Pinalia maingayi & $\sqrt{ }$ & $\sqrt{ }$ & \\
\hline 111. & Podochilus tenuis & $\sqrt{ }$ & $\sqrt{ }$ & $\sqrt{ }$ \\
\hline 112. & Polystachya concreta & $\sqrt{ }$ & $\sqrt{ }$ & $\sqrt{ }$ \\
\hline 113. & Renanthera elongata & $\sqrt{ }$ & $\sqrt{ }$ & $\sqrt{ }$ \\
\hline 114. & Robiquetia spathulata & $\sqrt{ }$ & $\sqrt{ }$ & $\sqrt{ }$ \\
\hline 115. & Spathoglottis plicata & $\sqrt{ }$ & $\sqrt{ }$ & $\sqrt{ }$ \\
\hline 116. & Stichorkis elegans & $\sqrt{ }$ & $\sqrt{ }$ & $\sqrt{ }$ \\
\hline 117. & Stichorkis viridiflora & $\sqrt{ }$ & $\sqrt{ }$ & \\
\hline 118. & Taeniophyllum pusillum & $\sqrt{ }$ & $\sqrt{ }$ & \\
\hline 119. & Tainia maingayi & $\sqrt{ }$ & $\sqrt{ }$ & \\
\hline 120. & Tainia wrayana & & $\sqrt{ }$ & $\sqrt{ }$ \\
\hline 121. & Thelasis micrantha & $\sqrt{ }$ & $\sqrt{ }$ & \\
\hline 122. & Thrixspermum amplexicaule & $\sqrt{ }$ & $\sqrt{ }$ & $\sqrt{ }$ \\
\hline 123. & Thrixspermum centipeda & $\sqrt{ }$ & $\sqrt{ }$ & $\sqrt{ }$ \\
\hline 124. & Thrixspermum duplocallosum** & & & $\sqrt{ }$ \\
\hline 125. & Thrixspermum trichoglottis & $\sqrt{ }$ & $\sqrt{ }$ & $\sqrt{ }$ \\
\hline 126. & Thrixspermum.calceolus & $\sqrt{ }$ & $\sqrt{ }$ & $\sqrt{ }$ \\
\hline 127. & Trichoglottis cirrhifera & $\sqrt{ }$ & $\sqrt{ }$ & $\sqrt{ }$ \\
\hline 128. & Trichotosia ferox & $\sqrt{ }$ & $\sqrt{ }$ & $\sqrt{ }$ \\
\hline 129. & Trichotosia gracilis & $\sqrt{ }$ & $\sqrt{ }$ & $\sqrt{ }$ \\
\hline
\end{tabular}


Table 1 continued

\begin{tabular}{lllll}
\hline No. & Species & Curtis (1894) & Turner (1995) & Current study \\
\hline 130. & Trichotosia rotundifolia & & $\sqrt{ }$ & \\
131. & Trichotosia velutina & $\sqrt{ }$ & $\sqrt{ }$ & $\sqrt{ }$ \\
132. & Vanilla griffithii & $\sqrt{ }$ & $\sqrt{ }$ & $\sqrt{ }$ \\
133. & Ventricularia tenuicaulis & $\sqrt{ }$ & $\sqrt{ }$ & $\sqrt{ }$ \\
134. & Zeuxine affinis & $\sqrt{ }$ & $\sqrt{ }$ & \\
135. & Zeuxine parvifolia & & $\sqrt{ }$ & 86 \\
136. & Zeuxine rupestris* & $\sqrt{ }$ & 118 & \\
Total & & 89 & & \\
\hline
\end{tabular}

$\sqrt{ }$, present

* Endemic to Penang as reported by Turner (1995)

** New record to Penang Hill

draught) was suggested for the reason it was not found during this study, the scenario better explained by the discovery of unhealthy small plants in a small population of another species, Zeuxine affinis at Government Hill which is the highest peak of Penang Hill system. Coelogyne velutina a new species described by de Vogel in 1992 based on specimens collected by Maingay from Government Hill was the only species not recorded by Turner (1995), but this species was recollected from the same locality in this study. Bulbophyllum bisetum listed by Curtis (1894) might be of wrong identification as the distribution of this species is from East Himalaya to Northern Thailand and was never mention in Seidenfaden and Wood (1992) and Turner (1995).

The comparison between the current study and that of Curtis (1894) recorded almost the same number of species 88 (Curtis, 1894) and 85 (current study) with 57 (57\%) species overlapped. The differences between the two lists could be due to species being overlooked and also by natural changes in orchid flora as orchids spread easily provided the environment is ideal for its germination and growth. In a nut shell, the orchid flora of Penang Hill is more or less intact, in spite of humans messing around in that area for more than a century. This is however, some light of hope for people involved in orchid conservation that even forests altered to some extent by human activities can retain most of their orchid flora.

The state government's decision to gazette the Penang Hill system as a Permanent Forest Reserve signifies their support towards conservation of the rich and unique biodiversity represented in this small pristine forest. At least Penang Hill could stand tall for as long as the world exists together with the natural treasures it houses including the ever adorable orchids, unless climatic changes and earth destruction occur. The previous record of $C$. goldschmidtiana, a rare and endemic species for Penang Hill and Baling, Kedah and the once presence $Z$. rupestris a narrowly endemic species to Penang Hill could also further justify and strengthen the grounds of conserving Penang Hill. Table 1 shows a comparison of the orchids found during this study with those listed by Curtis (1894) and Turner (1995). Figure 1 shows some of the beautiful orchids found during this study.

\section{Conclusion}

Penang Hill exhibits a great diversity of orchids relative to the small land area covered during this study. The 61 genera and 85 species portrayed an exceptionally rich orchid flora 

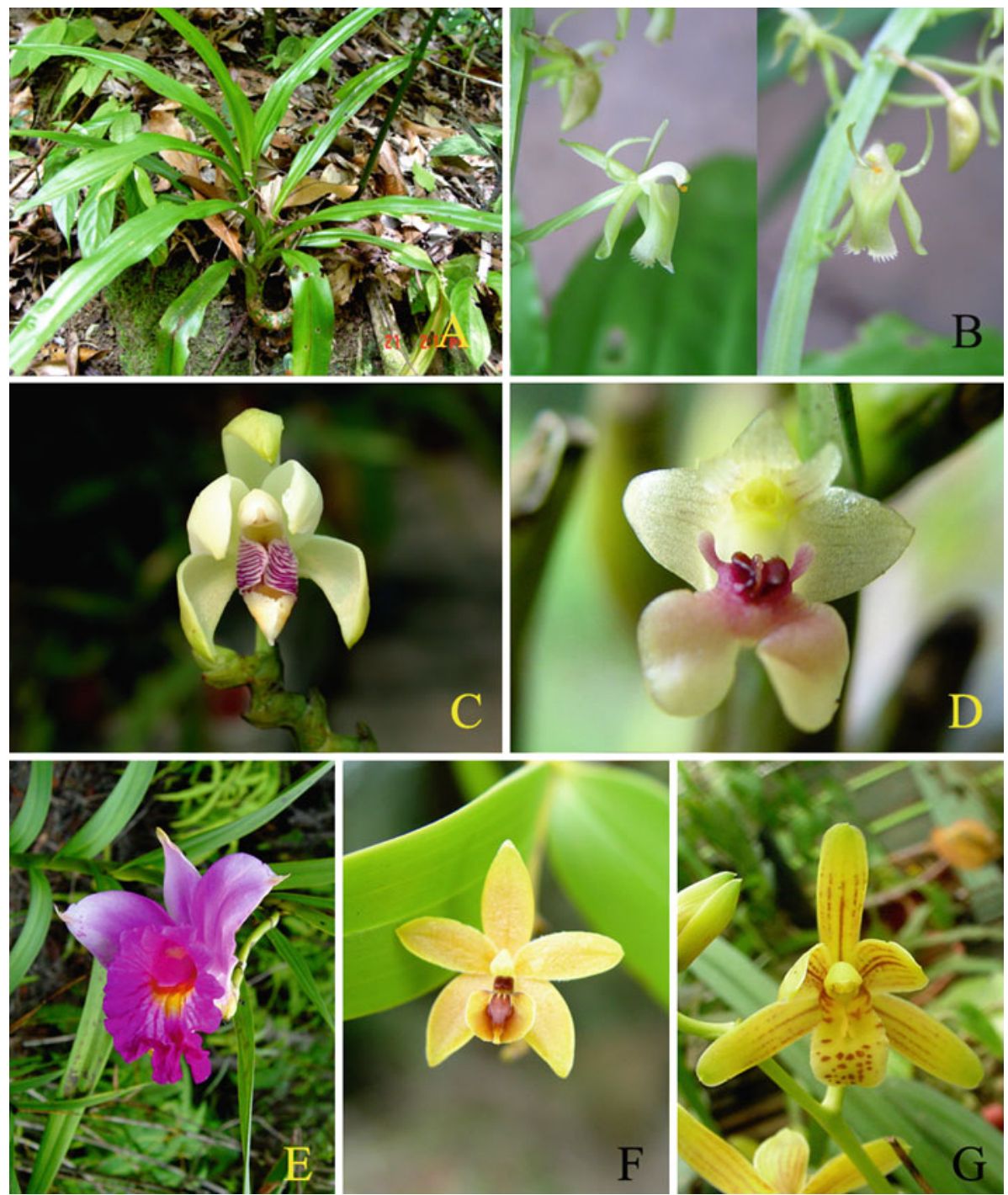

Fig. 1 Penang orchids species and new records*. a Lepidogyne longifolia*, b Liparis barbata*, c Bromheadia finlaysoniana, d Dendrobium convexa*, e Arundina graminifolia, f Callostylis pulchella, g Cymbidium haematodes*

found in the 18 trails in Penang Hill system. Seven new records are added to the orchid checklist for Penang. Overall, Penang Hill is still suitable for orchid growth as the area is now being designated as a Permanent Forest Reserve and the survival of some orchid species are better guaranteed unless human intervention and climatic changes were to occur. Flagship species like Paphiopedilum callosum var. sublaeve (Slipper orchid) and once widely distributed Grammatophyllum speciosum (Tiger orchid) are examples of Penang indigenous species which are threatened in the wild and conservation measures should be introduce to safe guard their existence. The two species endemic to Peninsular 
Malaysia namely $C$. goldschmidtiana and Z. rupestris which were previously recorded from Penang Hill should be further investigated to determined their true status in the wild.

Acknowledgments The above study was collaboration work between Malaysian government and South Korea, and was made possible through the generosity of many individuals and agencies. Firstly, we would like to acknowledge the Government of Malaysia for the research grants made available to the main author through IRPA-RM8 (08-02-04-0249), E-Science (08-02-04-0249-EA001) and Science fund (05-01-04SF0141), and the Korean Government through the Korean National Arboretum Grant (KNA1-1-4, 06-1). We would also extend our gratitude to the Penang Botanical Garden, Folia Malaysiana Heritage Foundation, Singapore Botanical Garden, RBG Kew Herbarium (KEW), University Malaya Herbarium (KLU), FRIM Herbarium (KEP), and Universiti Kebangsaan Malaysia Herbarium (UKMB) for allowing us to study their specimens and other assistance rendered during this study. Our sincere thanks also go to individuals that unselfishly shared their experiences and time in assisting us in the field, Dato Seri Lim Chong Kiat (Folia Malaysiana Foundations), Mr. Baharuddin Sulaiman (USM) and Mr. Hamid (Penang Botanical Garden).

Open Access This article is distributed under the terms of the Creative Commons Attribution Noncommercial License which permits any noncommercial use, distribution, and reproduction in any medium, provided the original author(s) and source are credited.

\section{References}

Bridson D, Forman L (1989) The herbarium handbook. Lubrecht \& Cramer Ltd, Wedmore

Burkill IH (1966) Botanical collectors and collections and collecting places in the Malay Peninsula. Folia Malaysiana 3:79-152

Cheah SS (2005) Diversity of terrestrial and lithophytic orchids at selected trails in Penang Hill. B.Sc.

Thesis, Universiti Putra Malaysia, Serdang (unpublished)

Comber JB (1990) Orchids of Java. The Bentham-Moxom Trust, Royal Botanic Garden, Kew

Comber JB (2001) Orchids of Sumatra. Natural History Publications (Borneo), Kota Kinabalu

Curtis C (1894) A catalogue of the flowering plants \& ferns found growing wild in the Island of Penang.

J Strait Br R Asiat Soc 25:67-173

Holtum RE (1957) Orchids of Malaya. Singapore Botanic Garden, Government Printing Office, Singapore http://orchid.unibas.ch/site.home.php. Accessed 12 May 2011

http://apps.kew.org/wcsp/home. Accessed 12 May 2011

Khor KP, Kam SP, Chik A, Raman M, Leong YK (1991) Penang Hill: the need to save our natural heritage. Friends of Penang Hill, Malaysia

Loy CM (2005) Diversity of epiphytic orchids at selected trails in Penang Hill. B.Sc. Thesis, Universiti Putra Malaysia, Serdang, Malaysia (unpublished)

Seidenfaden G, Wood JJ (1992) The orchids of Peninsular Malaysia and Singapore. Olsen \& Olsen, Fredensborg

Turner IM (1995) A catalogue of the vascular plants of Malaya. Gardens’ Bull Singap 47(2):599-620 